\title{
EXPRESSION PATTERN OF GLYCOCONJUGATES IN THE BIDDERIAN AND OVARIAN FOLLICLES OF THE BRAZILIAN TOAD Bufo ictericus ANALYZED BY LECTIN HISTOCHEMISTRY
}

\author{
FARIAS, C. F., AZEVEDO, R. A. and BRITO-GITIRANA, L. \\ Laboratory of Animal and Comparative Histology, Department of Histology and Embryology, \\ Federal University of Rio de Janeiro, Av. Trompowsky, s/n, CCS, B1-017, Cidade Universitária, \\ Ilha do Fundão, CEP 21540-970, Rio de Janeiro, RJ, Brazil \\ Correspondence to: Lycia de Brito-Gitirana, Laboratory of Animal and Comparative Histology, \\ Department of Histology and Embryology, Federal University of Rio de Janeiro, \\ Av. Trompowsky s/n, CCS, B1-017, Cidade Universitária, Ilha do Fundão, CEP 21540-970, \\ Rio de Janeiro, RJ, Brazil, e-mail: lyciabg@ufrj.br \\ Received March 10, 2004 - Accepted September 3, 2004 - Distributed February 28, 2006
}

(With 12 figures)

\begin{abstract}
The Bidder's organ and ovary of the Brazilian toad Bufo ictericus were studied by light microscopy, using hematoxylin-eosin (HE) and periodic acid Schiff (PAS) staining. The expression and distribution of carbohydrate moieties was analyzed by lectin histochemistry, using 8 lectins with different carbohydrate specificities: Ulex europaeus (UEA I), Lens culinaris (LCA), Erythrina cristagalli (ECA), Arachis hypogaea (PNA), Ricinus communis (RCA I), Aleuria aurantia (AAA), Triticum vulgaris (WGA), and Glycine maximum (SBA). The results showed that the Bidderian zona pellucida presented $\alpha$-mannose, $\alpha$-L-fucose, $\beta$-D-galactose, $\mathrm{N}$-acetyl-D-glucosamine, and $\alpha / \beta-\mathrm{N}$-acetyl-galactosamine residues. The Bidderian follicular cells showed the presence of $\beta$-D-galactose and $\mathrm{N}$-acetyl-D-glucosamine. In the extracellular matrix, $\alpha$-mannose and $\alpha / \beta-\mathrm{N}$-acetyl-galactosamine residues were detected. The ovarian zona pellucida showed $\alpha$-L-fucose, $\mathrm{N}$-acetyl-D-glucosamine, $\alpha / \beta$-N-acetyl-galactosamine residues, and $\alpha$-mannose and $\mathrm{N}$-acetyl-D-glucosamine residues were detected in the follicular cells. Thus, the zona pellucida in both organs contains $\mathrm{N}$-acetyl-D-glucosamine, and $\alpha / \beta-\mathrm{N}$-acetyl-galactosamine residues. $\alpha-\mathrm{L}$-fucose residues were detected in the zona pellucida of both organs, using different lectins. Considering that $\beta$-D-galactose residue was absent from ovary but present in the Bidder's organ, this sugar residue may play an important role in follicle development, blocking the Bidderian follicles and preventing further development of the Bidder's organ into a functional ovary.
\end{abstract}

Keywords: Bidder's organ, ovary, Bufo ictericus, lectins, histochemistry.

\section{RESUMO}

\section{Padrão de expressão de glicoconjugados nos folículos Bidderianos e ovarianos do sapo brasileiro Bufo ictericus, analisado por histoquímica de lectin}

O órgão do Bidder e o ovário do sapo Bufo ictericus foram analisados por meio de microscopia de luz, utilizando a coloração pela hematoxilina-eosina (HE) e o método do ácido periódico de Schiff (PAS). A expressão e a distribuição de carboidratos foram verificadas por meio da histoquímica com lectinas, tendo sido utilizadas 8 lectinas com diferentes especificidades para carboidratos (Ulex europaeus (UEA I), Lens culinaris (LCA), Erythrina cristagalli (ECA), Arachis hypogaea (PNA), Ricinus communis (RCA I), Aleuria aurantia (AAA), Triticum vulgaris (WGA) e Glycine maximum (SBA). Os resultados mostraram que a zona pelúcida Bidderiana apresenta resíduos de $\alpha$-mannose, $\alpha$-L-fucose, $\beta$-D-galactose, $\mathrm{N}$-acetil-D-glicosamine e $\alpha / \beta-\mathrm{N}$-acetil-galactosamina. As células foliculares Bidderianas mostraram a presença de $\beta$-D-galactose e $\mathrm{N}$-acetil-D-glicosamina. Na matriz de extracelular foram detectados resíduos de $\alpha$-mannose e $\alpha / \beta$ - $\mathrm{N}$-acetil-galactosamina. Resíduos de $\alpha$-L-fucose, $\mathrm{N}$-acetyl-D-glicosamina 
e $\alpha / \beta$-N-acetil-galactosamina foram evidenciados na zona pelúcida ovariana, enquanto na célula folicular foi detectado o resíduo de $\alpha$-mannose e de $\mathrm{N}$-acetil-D-glicosamina. Assim, a zona pelúcida, em ambos os órgãos, contém resíduos de $\mathrm{N}$-acetil-D-glicosamina e $\alpha / \beta-\mathrm{N}$-acetil-galactosamina. O resíduo de $\alpha$-L-fucose foi detectado na zona pelúcida de ambos os órgãos, mas utilizando-se diferentes lectinas. Considerando que o resíduo de $\alpha$-D-galactose é ausente no ovário, mas presente no órgão de Bidder, a $\alpha$-D-galactose pode ter um papel importante no controle do desenvolvimento folicular, bloqueando o desenvolvimento dos folículos Bidderianos e impedindo que o órgão de Bidder se transforme em um ovário funcional.

Palavras-chave: órgão de Bidder, ovário, Bufo ictericus, lectinas, histoquímica.

\section{INTRODUCTION}

Male toads of the Bufonidae Family have a rudimentary ovary, named the Bidder's organ, which has been used as a systematic character (Duellman $\&$ Trueb, 1994). The Bidder's organs are located in the anterior end of the gonads, between the body fat and the gonad itself (Tanimura \& Iwasawa, 1992; Spengel, 1876). Some authors state that, if the testes are removed experimentally, the Bidder's organs develop into functional ovaries; such gonadal conversion represents a morphological strategy for the specimen's reproduction (Wake, 1980; Moriguchi et al., 1991; Pancak-Roessler \& Norris, 1991; Tanimura \& Iwasawa, 1992). In Bufo ictericus Spix 1824 males, the Bidder's organ possesses a cortical region that exhibits Bidderian follicles in different stages of development, and a medullar region (Farias et al., 2002). Female anurans exhibit a pair of ovaries; each ovary consists of a thin sheath of connective tissue, the ovisac, enclosing the ovarian follicles in different stages of development. The ovarian follicles have germ cells surrounded by follicular cells (Duellman \& Trueb, 1994).

Lectins are nonimmune proteins or glycoproteins derived from plants, animals, or microorganisms. They are specific to terminal or subterminal carbohydrate residues to which they bind noncovalently (Liener et al., 1986, Desantis et al., 2003). Besides, lectin specificity for sugar residues has been extensively used as a histochemical probe to characterize various cells types in various stages of differentiation and maturation (Damjanov, 1987, Alroy et al., 1988; Walker, 1989; Spicer \& Schulte, 1992). Regulated glycosylation is essential for cell interactions during growth and differentiation. Then, cellular carbohydrates are also important for cell recognition and adhesion events (Sharon \& Lis, 1989).
Carbohydrates play a major role in the fertilization process of mammals, birds and sea urchins. The extracellular egg coat, the zona pellucida, contains a number of glycoproteins, which are species-specific and trigger sperm-egginteraction (Wassarman et al.,, 1999; Mello, 1989; Duellman \& Trueb, 1994; Alves et al., 1997; 1998; Gheri et al., 2000).

Studies on glycoconjugates in amphibian ovaries are scarce, and no data about carbohydrate moieties in Bidderian follicles are currently available in the literature. Thus, the purpose of this work is to investigate the distribution of carbohydrate in the Bidderian and ovarian follicles of the Brazilian toad Bufo ictericus, correlating the similarities between both organs.

\section{MATERIALS AND METHODS}

\section{Animals}

The fifteen adult males and nine females of Bufo ictericus used in this study were collected according to Brazilian laws (license 080/2000DIFAS/DIREC/IBAMA). All the animals came from Resende in Rio de Janeiro State.

\section{Tissue preparation and staining}

Bidder's organ and ovary fragments were fixed by immersion in Bouin's liquid for $18 \mathrm{~h}$ at $4{ }^{\circ} \mathrm{C}$. After rinsing in $70 \%$ ethanol, the fragments were processed according to the standard histological technique for paraffin embedding. For morphological studies, $5 \mu \mathrm{m}$ serial sections were stained with hematoxylin-eosin. Periodic acid Schiff (PAS) staining was employed to detect neutral glycoproteins (Lillie \& Fulmer, 1976).

\section{Lectin histochemistry}

The biotinylated lectins (kit Vector $\mathrm{n}^{\circ} \mathrm{BK}$ 1000, BK 2000, BK 3000, Burlingame CA, 
USA) listed in Table 1 were used. Once dewaxed and re-hydrated, tissue sections were immersed in $3 \% \mathrm{H}_{2} \mathrm{O}_{2}$ for $10 \mathrm{~min}$. to suppress endogenous peroxidase activity, rinsed in $0.05 \mathrm{M}$ phosphatebuffered saline (PBS), pH 7.4, and incubated in lectin solution with appropriate dilutions $(1: 4,000)$ for $1 \mathrm{~h}$ at room temperature. After 3 rinses in PBS, peroxidase activity was observed by incubation in a solution containing $0.05 \%$ 3,3'- diaminobenzidine (DAB) and $0.005 \% \mathrm{H}_{2} \mathrm{O}_{2}$ in $0.05 \mathrm{M}$ PBS (pH 7.4) for $1 \mathrm{~min}$ at room temperature before dehydration and mounting. The incubation medium with buffer but without lectin was used as control for the lectins' reaction.

\section{RESULTS}

In B. ictericus, the Bidder's organ has a typical medullar region and a cortical region with Bidderian follicles in different stages of development, and shows an intimate relationship to the testis. The ovary consists of an ovisac enclosing the ovarian follicles in different stages of development. The ovarian follicles consist of germ cells surrounded by follicular cells (Fig. 1 and 2). The PAS method reveals the presence of neutral glycoproteins in the zona pellucida of both organs.

Lectin-binding patterns in the Bidder's organs and ovaries of Brazilian toad are summarized as follows (Tables 2 and 3):
- UEA-I. A moderate reaction in the Bidderian zona pellucida is observed, but positive reaction is detected neither in follicular cell

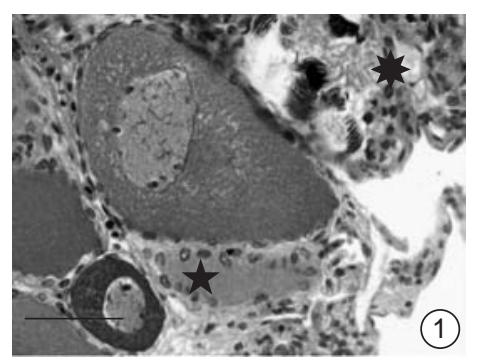

Fig. 1 - Light micrograph showing the intimate association between Bidder's organ ( $\star$ ) and the testis (*). HE-staining, Bar $=2 \mu \mathrm{m}$.

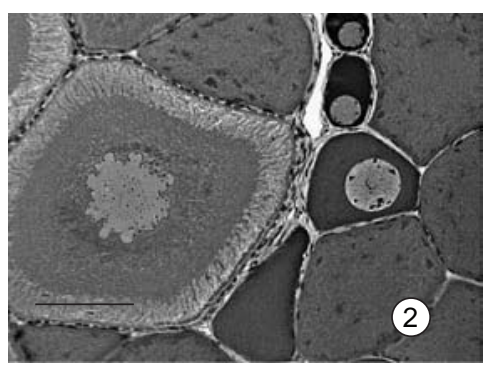

Fig. 2 - Light micrograph of ovarian follicles. HE-staining, Bar $=4 \mu \mathrm{m}$.

TABLE 1

Lectin used in the present study, its source and inhibitory sugars.

\begin{tabular}{|c|l|l|l|c|}
\hline Lectin abbrev. & \multicolumn{1}{|c|}{ Source of lectin } & \multicolumn{1}{|c|}{ Inhibitory sugar } & \multicolumn{1}{|c|}{ Sugar specificity } & Cat. Vector N \\
\hline UEA-I & Ulex europaeus & Fucose & $\begin{array}{l}\alpha \text {-L-fucose } \\
(\text { Golstein \& Poretz, 1986) }\end{array}$ & B-1065 \\
\hline LCA & Lens culinaris & Mannose & $\begin{array}{l}\alpha \text {-manose } \\
(\text { Golstein \& Poretz, 1986) }\end{array}$ & B-1045 \\
\hline ECA & Erythrina Cristagalli & Lactose & $\begin{array}{l}\text { Lactose } \\
(\text { Golstein \& Poretz, 1986) })\end{array}$ & L-1140 \\
\hline PNA & Arachis hypogaea & Galactose & $\begin{array}{l}\beta \text {-D-galactose } \\
(\text { Desantis } \text { et al., 2003) }\end{array}$ & B-1075 \\
\hline RCA I & Ricinus communis & Galactose & $\begin{array}{l}\beta \text {-galactose } \\
(\text { Golstein \& Poretz, 1986) }\end{array}$ & B-1085 \\
\hline AAA & Aleuria aurantia & Fucose & $\begin{array}{l}\alpha \text {-L-fucose } \\
(\text { Golstein \& Poretz, 1986) }\end{array}$ & L-1390 \\
\hline WGA & Triticum vulgaris & N-acetilglucosamine & $\begin{array}{l}\text { N-GlcNAc } \\
(\text { Fang \& Welsch, 1995) }\end{array}$ & BK-1000 \\
\hline SBA & Glycine maximum & N-acetilgalactosamine & $\begin{array}{l}\alpha / \beta-N-G a l N A c ~ \\
(\text { Fröjdman } \text { et al., 1992) }\end{array}$ & BK-1000 \\
\hline
\end{tabular}


TABLE 2

Summary of lectin binding to Bidder's organ.

\begin{tabular}{|l|l|c|c|c|}
\hline Lectin & Sugar specificity & Zona pellucida & Follicular cell & Extracellular matrix \\
\hline UEA-I & $\alpha$-L-fucose & ++ & - & - \\
\hline LCA & $\alpha$-mannose & $-/+$ & - & +++ \\
\hline ECA & Lactose & - & - & - \\
\hline PNA & $\beta$-D-galactose & ++ & ++ & + \\
\hline RCA I & $\beta$-galactose & - & - & - \\
\hline AAA & $\alpha$-L-fucose & - & + & - \\
\hline WGA & N-GlcNAc & +++ & - & ++ \\
\hline SBA & $\alpha / \beta-N-G a l N A c$ & $+/++$ & & - \\
\hline
\end{tabular}

$(+++)$ strong; (++) moderate; (+) weak; and (-) negative reactions.

TABLE 3

Summary of lectin binding to ovary.

\begin{tabular}{|c|c|c|c|}
\hline Lectin & Sugar specificity & Zona pellucida & Follicular cell \\
\hline UEA I & $\alpha$-L-fucose & - & - \\
\hline LCA & $\alpha$-mannose & - & - \\
\hline ECA & Lactose & - & - \\
\hline PNA & $\beta$-D-galactose & - & - \\
\hline RCA I & $\beta$-galactose & - & - \\
\hline AAA & $\alpha$-L-fucose & $-/+$ & + \\
\hline WGA & N-GlcNAc & +++ & - \\
\hline SBA & $\alpha / \beta-N-G a l N A c$ & $-/+$ & \\
\hline
\end{tabular}

$(+++)$ strong; (++) moderate; (+) weak; and (-) negative reactions .

nor in extracellular matrix (Fig. 3). UEA-I does not show any reactivity in ovaries;

- AAA. In the Bidder's organ, no reaction is observed. In ovary, a weak to absent reaction is found in the zona pellucida. Lectin binding sites for AAA are absent in the follicular cells (Fig. 4);

- LCA. A strong reaction is visible in the Bidderian extracellular matrix (Fig. 5); however, follicles with a weak reaction are detected in the later previtellogenesis and vitellogenesis stages. In the ovaries, a very weak reaction is present in the follicular cell but absent from the zona pellucida (Fig. 6);

- ECA. Lectins sites for ECA are absent from Bidderian and ovarian follicles;

- PNA. Labeled PNA binds moderately to follicular cells and zona pellucida, and very weakly in the extracellular matrix of the Bidder's organ (Fig. 7). No reaction is detected in follicular cell and zona pellucida of the ovaries (Fig. 8);

- RCA I. Lectin binding sites for RCA I are absent in the follicular cell and zona pellucida of both organs;

- WGA. A strong reaction is observed in the zona pellucida of follicles in the later previtellogenesis and vitellogenesis stages in the Bidder's organ and ovary. No reaction is observed in the extracellular matrix of the Bidder's organ (Figs. 9 and 10); and

- SBA. Positive reaction in the Bidderian zona pellucida is observed in the early previtellogenesis stages but it becomes weak in the later stages (Fig. 11). In ovary, the positive reaction is absent in the early stages, but present in the later previtellogenesis stage (Fig. 12). 


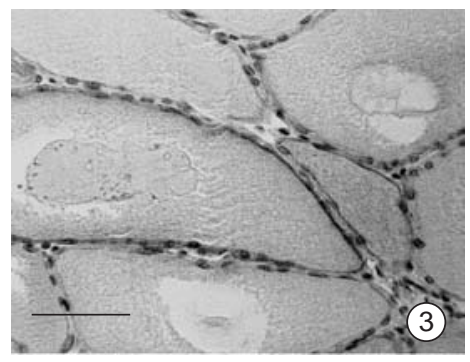

Fig. 3 - Bidder's organ, UEA-reactivity. Moderate reaction in the zona pellucida. $\mathrm{Bar}=2 \mu \mathrm{m}$.

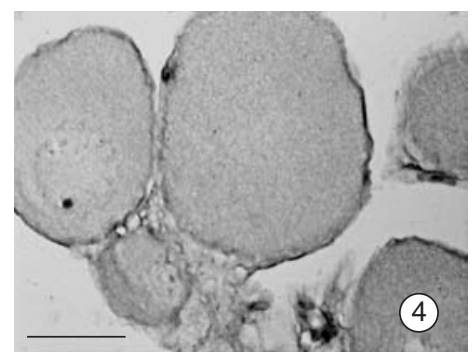

Fig. 4 - Ovary, AAA-staining. Weak to absent reaction in the zona pellucida and absent from the follicular cells. $\mathrm{Bar}=2 \mu \mathrm{m}$.

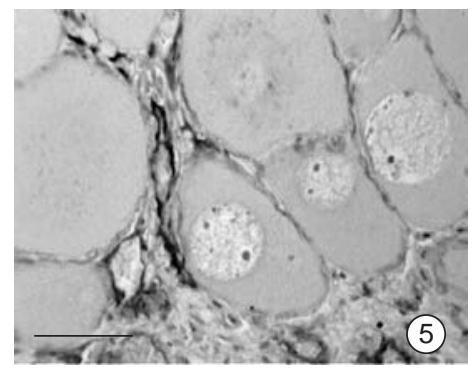

Fig. 5 - Bidder's organ, LCA-staining. Strong reaction in the extracellular matrix. Bar $=2 \mu \mathrm{m}$.

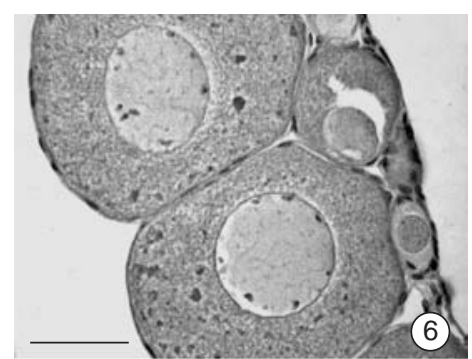

Fig. 6 - Ovary, LCA-staining. Weak reaction in the follicular cells and absent from the Zona pellucida. Bar $=2 \mu \mathrm{m}$.

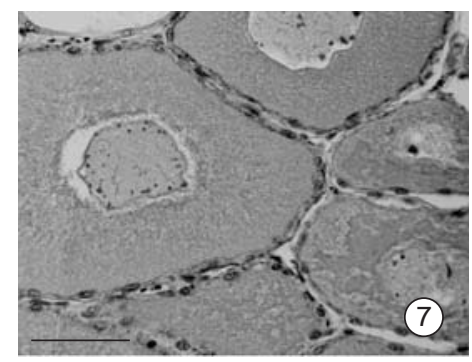

Fig. 7 - Bidder's organ, PNA-staining. Moderate reaction in the zona pellucida and in the follicular cells. $\mathrm{Bar}=2 \mu \mathrm{m}$.

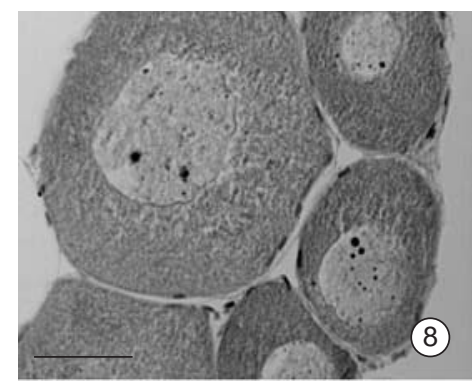

Fig. 8 - Ovary, PNA-staining. Note negative reaction. Bar $=2 \mu \mathrm{m}$.

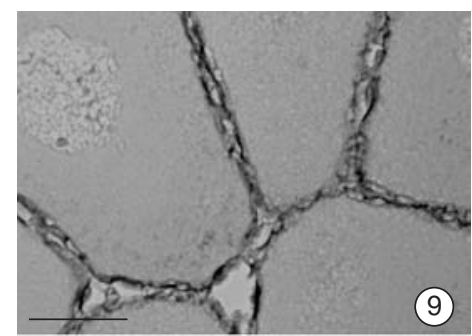

Fig. 9 - Bidder's organ, WGA-staining. Strong reaction in the zona pellucida. Bar $=2 \mu \mathrm{m}$.

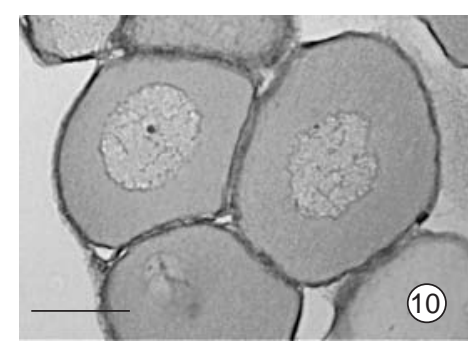

Fig. 10 - Ovary, WGA-staining. Strong reaction in the zona pellucida. $\mathrm{Bar}=2 \mu \mathrm{m}$. 


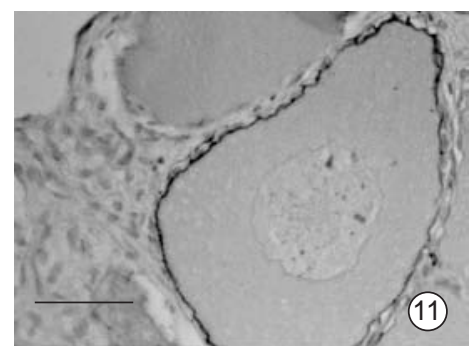

Fig. 11 - Bidder's organ. SBA-staining. Note positive reaction in the zona pellucida in early previtelogenesis stages. Bar $=2 \mu \mathrm{m}$.

\section{DISCUSSION}

The present study demonstrated that the Bidder's organ has binding sites for LCA, UEA-I, WGA, and SBA, whereas the ovary shows binding sites for LCA, AAA, WGA and SBA but not for UEA-I. Nevertheless, there are differences regarding the localization of sugar residues expression and nature of oligosaccharide linkage.

The result of PAS reaction that reveals neutral carbohydrate polymers rich in hexose (Kiernan, 1990) is congruent with previous observations of the zona pellucida of the vertebrate (Fang \& Welsch, 1995; Wolpert et al., 1998; Farias et al., 2002).

In Bufo ictericus, in both organs the zona pellucida contains N-acetyl-D-glucosamine, $\alpha / \beta$-N-acetyl-galactosamine, and $\alpha$-L-fucose residues, but $\beta$-D-galactose residue is exclusive for the Bidde-rian zona pellucida. The $\alpha$-L-fucose residues were detected in both organs, albeit by different lectins. This different reaction pattern was probably due to the different isolation sources, i.e., from green plants (UEA-I) and fungus (AAA) (Goldstein \& Poretz, 1986).

Sexual development and differentiation of some vertebrate gonads involve changes considering the type and the distribution of different proteins and glycoproteins (Fröjdman et al., 1992). Studies of murine ovaries suggest that the glycoconjugates of the zona pellucida undergo a series of cytochemical changes following maturation, ovulation, and fertilization of ovarian oocytes (Shimizu \& Yamada, 1986; Wassarman et al., 1999). In the sea urchin Paracentrotus lividus, WGA and SBA showed high affinity to the vitelline membrane of unfertilized eggs. On the

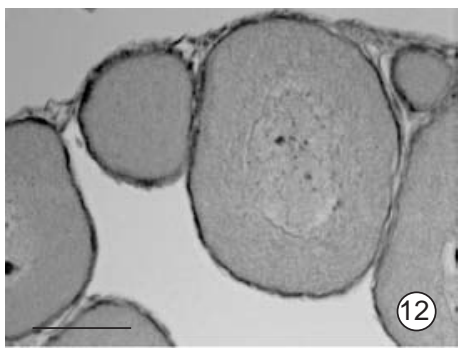

Fig. 12 - Ovary. SBA-staining. Positive reaction in the zona pellucida in later previtelogenesis stages. $\mathrm{Bar}=2 \mu \mathrm{m}$.

other hand, PNA labeling is weak in the same site, indicating developmental changes in cell surface, leading to changes in cell-environment interactions (Contini et al., 1992).

Gheri et al. (2000) pointed out that lectin histochemistry is important to define the maturation phases of ovarian follicles during embryonic development of chick ovary. At the same time, it has revealed a peculiar evolutionary pattern of the oogonia in different cortical ovarian zones. Fang \& Welsch (1995), studying the distribution of carbohydrate moieties in lancelet (Branchiostoma belcheri) oocytes in different stages of development, suggested that the carbohydrate content varied with the oocyte development and maturation. In our study, lectin histochemistry was a powerful instrument to detect different sugar residues in organs that, despite their morphological similarities, has chemical differences.

Mozingo \& Hedrick (1999), studying the distribution of lectin binding sites in Xenopus laevis egg jelly, pointed out that $\mathrm{N}$-acetyl-D-glucosamine block the fertilization by preventing sperm from penetrating the jelly. Onikate et al. (2000) also suggested that $\mathrm{N}$-acetyl-D-glucosamine may be important for the induction of the acrosome reaction in newt (Cynops pyrrhogaster). In B. ictericus, $\mathrm{N}$-acetyl-glucosamine was detected in zona pellucida and follicular cells of both organs. Therefore, this sugar residue occurs in the germ follicles of the ovary, and is preserved during their transport through the oviduct, which is responsible for egg jelly secretion.

Some authors state that the Bidder's organ may develop into functional ovaries (Duellman \& Trueb, 1994). We have demonstrated that the 
Bidder's organ has characteristic structural features able to produce sexual cells (Farias et al., 2002), and the presence of $\beta$-D-galactose residue supports the hypothesis that the Bidder's organ is able to develop into a functional ovary. Nevertheless, $\beta$-D-galactose residue is specific in the Bidder's organ of Bufo ictericus. Thus, $\beta$-D-galactose residues block the Bidderian follicles in males, preventing further development of the Bidder's organ into a functional ovary.

\section{REFERENCES}

ALROY, J., UCCI, A. A. \& PERIERA, M. E. A., 1988, Lectin histochemistry: an update. In: R. A. de Lellis, (ed) Advances In Immunohistochemistry. Raven Press, New York.

ALVES, A. P., MULLOY, B., DINIZ, J. A. \& MOURÃO, P. A. S., 1997, Sulfated polyssacarides from the egg jelly layer are species-specific inducers of acrosomal reaction in sperms of sea urchins. J. Biol. Chem., 272(11): 6965-6971.

ALVES, A. P., MULLOY, B., MOY, G. W., VACQUIER, V. D. \& MOURÃO, P. A. S., 1998, Females of the sea urchin Strongylocentrotus purpuratus differ in the structures of their egg jelly sulfated fucans. Glycobiol., 8(9): 939-946.

CONTINI, A., FALUGI, C. \& FASULO, S., 1992, Development regulation of lectin-binding patterns in Paracentrotus lividus gonads, gametes, and early embryos. Acta Histochem., 92(2): 179-189.

DAMJANOV, I., 1987, Biology of disease. Lectin cytochemistry and histochemistry. Lab. Invest., 57: 5-17.

DESANTIS, S., CORRIERO, A., ACONE, F., SUBAN, D., CIRILlO, F., PALMIERI, G., DE METRIO, G., 2003, Lectin histochemistry on the dorsal epidermis of the Breton dog. Acta Histochem., 105(1): 73-79.

DUELLMAN, W. E. \& TRUEB, L., 1994, Biology of Amphibians. The Johns Hopkins University Press Ltd, Baltimore.

FANG, Y. Q. \& WELSCH, U., 1995, A histochemical study of the distribution of lectin binding sites in the developing oocytes of the lancelet Branchiostoma belcheri. Cell Tiss. Res., 280: 427-434.

FARIAS, C. F., CARVALHO-E-SILVA, S. P. \& DE BRITO-GITIRANA, L., 2002, Bidder's organ of Bufo ictericus: a light an electron microscopy analysis. Micron, 33: 673-679.

FRÖJDMAN, K., MALMI, R. \& PELLINIEMI, L. J., 1992, Lectin-binding carbohydrates in sexual differentiation of rat male and female gonads. Histochem., 97: 469-477.

GHERI, G., SGAMBATI, E. \& BRYK, G., 2000, Lectin binding in the ovary of the chick embryo and newborn. Eur. J. Morph., 38(1): 51-62.

GOLDSTEIN, I. J. \& PORETZ, R. D., 1986, Isolation, physicochemical characterization, and carbohydratebinding specificity of lectins. Cap 2, pp. 32-246. In: I. E.
Liener, N. Sharon \& I. J. Goldstein, 1986, The lectins, properties, functions and applications in biology and medicine. Orlando: Academic press., 598p.

KIERNAN, J. A., 1990, Histological and Histochemical Methods-Theory and Practice. $2^{\text {nd }}$ ed. Frankfurt: Pergamon press., 431p.

LIENER, I. E., SHARON, N., GOLDSTEIN, I. J., 1986, The lectins, properties, functions and applications in biology and medicine. Orlando, Academic Press, 598p.

LILLIE, R. D. \& FULLMER, H. M., 1976, Histopathological Technic and Pratical Histochemistry. $4^{\text {th }}$ ed. Mc Graw Hill Book Co, New York.

MELLO, R. A., 1989, Embriologia Comparada e Humana. Livraria Atheneu Editora, Rio de Janeiro, Brasil.

MORIGUCHI, Y., TANIMURA, A. \& IWASAWA, H., 1991, Annual changes in the Bidder's organ of the toad Bufo japonicus formosus: Histological observation. Sci. Rep. Niigata Univ., 28: 11-17.

MOZINGO, N. M. \& HEDRICK, J. L., 1999, Distribution of lectin binding sites in Xenopus laevis egg jelly. Dev. Biol., 210(2): 428-439.

ONIKATE, K., TAKAI, H., UKITA, M., MIZUNO, J. I., SASAKI, T. \& WATANABE. A., 2000, Significance of egg-jelly substances in the internal fertilization of the newt, Cynops pyrrhogaster. Comp. Biochem. Physiol. B. Biochem. Mol. Biol., 126(2): 121-128.

PANCAK-ROESSLER, M. K. \& NORRIS, D. O., 1991, The effects of orchidectomy and gonadotropins on steroidogenesis and oogenesis in Bidder's organs of the toad Bufo woodhousii. J. Exp. Zool., 260: 323-336.

SHARON, N. \& LIS, H., 1989, Lectins as cell recognition molecules. Science, 246: 227-234.

SHIMIZU, S. \& YAMADA, K., 1986, The cytochemistry of glycoconjugates in the zona pellucida of murine ovarian oocytes and two-cell embryos. Histochem. J., 18: 357-363.

SPICER, S. S. \& SCHULTE, B. A., 1992, Diversity of cell glycoconjugates shown histochemically: a perspective. J. Histochem. Cytochem., 40: 1-38.

TANIMURA, A. \& IWASAWA, H., 1992, Ultrastructural observations of the ovary and Bidder's organ in young toad, Bufo japonicus formosus. Sci. Rep. Niigata Univ., 29: 2733 .

WAKE, M. H., 1980, The reproductive biology of Nectophrynoides malcomi (Amphibia: Bufonidae), with comments on the evolution of reproductive modes in the genus Nectophrynoides. Copeia, 2: 193-209.

WALKER, R. A., 1989, The use of lectins in histopathology. Pathol. Res. Pract., 185: 826-835.

WASSARMAN, P., CHEN, J., COHEN, N., LITSCHER, E., LIU, C., QI, H. \& WILLIAMS, Z., 1999, Structure and function on the mammalian egg zona pellucida. J. Exp. Zool., 285(3): 251-258.

WOLPERT, L., BEDDINGTON, V., BROCKES, J., JESSELL, T., LAWRENCE, T. \& MEYEROWITZ, E., 1998, Principles of Development. $1^{\text {st }}$ Ed. Oxford University Press., 483p. 